\title{
Evaluation of factors that affect the spatial distribution of alien shrubs to monitor their invasion in a Pampa protected landscape in Tandil, Argentina
}

\section{María Isabel Márquez ${ }^{1}$, María Julia Kristensen², Juan Manuel Lavornia $^{3}$ and Santiago Linares ${ }^{4}$}

\begin{abstract}
${ }^{1}$ Instituto Patagónico de Ciencias Sociales y Humanas (IPCSH). Centro Científico Tecnológico - Centro Nacional Patagónico (CCT CONICET-CENPAT). Blvd. Brown 2915. (9120) Puerto Madryn. Chubut, Argentina. E-mail: mmarquez@cenpatconicet.gob.ar.

${ }^{2}$ Instituto de Geomorfología y Suelos (IGS). Facultad de Ciencias Naturales y Museo. Universidad Nacional de La Plata. Calle 1 no 644. (1900) La Plata. Buenos Aires, Argentina.

${ }^{3}$ Instituto de Ciencias Polares (ICPA). Universidad Nacional de Tierra del Fuego. Fuegia Vasket 251. (9410) Ushuaia. Tierra del Fuego, Argentina. And Centro de Investigaciones y Estudios Ambientales (CINEA). Facultad de Ciencias Humanas. Universidad Nacional del Centro de la Provincia de Buenos Aires. Campus Universitario Paraje $\mathrm{A}^{\text {o }}$ Seco. (7000) Tandil. Buenos Aires, Argentina.

${ }^{4}$ Centro de Investigaciones Geográficas (CIG). Instituto de Geografía, Historia y Ciencias Sociales (CONICET). Facultad de Ciencias Humanas. Universidad Nacional del Centro de la Provincia de Buenos Aires. Campus Universitario Paraje $\mathrm{A}^{\mathrm{o}}$ Seco. (7000) Tandil. Buenos Aires, Argentina.
\end{abstract}

Abstract. Invasive alien plants which replace native species represent a global threat that compromises biodiversity conservation by simplifying and homogenizing the landscape. The present study focuses on the problem of invasions in a mountainous area of the pampas (Tandil, Argentina) where several alien shrubs behave as invaders displacing a high diversity of native grassland. The aim of the study was to analyze, by means of geographical information system, the distribution of the most conspicuous alien shrub populations in relation to natural and anthropogenic factors in a protected area of landscape of the pampa region, in order to contribute to decision making and management based on knowledge. The selected working areas were those with spontaneous vegetation, conducting unsupervised classification of SPOT satellite images. A number of points in invaded areas were georeferenced in field to control the classification made by geographical information system. To measure the influence of the factors analyzed in the dispersal processes of the species spatial logistic regression techniques were used. Results showed that $20.40 \%$ of the study area was occupied by alien species of which $11.06 \%$ were tree

Received

June 8, 2019

Accepted

August 25, 2019

Available on line: August 25, 2019

Released

Augusto 31, 2019

Full Text Article 
plantations made by man and $9.34 \%$ corresponded to three alien shrub species distributed invading different landscape sections: Genista monspesullana occupied 307.85 ha, Rubus ulmifolius 237.82 ha and Spartium junceum 126.55 ha. In order to explain $R$. ulmifolius propagation all the analysed variables except quarries and pits were significant, but streets, roads and trails and stone fences had a stronger incidence. For $S$. junceum the significant explanatory variables were quarries and pits, altitude and slope. For $G$. monspesullana the explanatory variable was streets, roads and trails.

Keywords: Biological invasions; Invasive alien plants; Geographical Information System; Spatial logistic regression; Pampa grasslands.

Resumen. Evaluación de los factores que afectan la distribución espacial de arbustos exóticos para monitorear su invasión en un Paisaje Protegido de las Pampas, en Tandil, Argentina. Las plantas exóticas invasoras que sustituyen a las especies nativas representan una amenaza global que compromete la conservación de la biodiversidad al simplificar y homogeneizar el paisaje. El presente estudio se centra en el problema de las invasiones que ocurre en una zona montañosa de las Pampas (Tandil, Argentina) donde varios arbustos exóticos se comportan como invasores desplazando a la alta diversidad de los pastizales nativos. El objetivo de este estudio fue analizar mediante un sistema de información geográfica la distribución de las poblaciones más conspicuas de arbustos exóticos, en relación a factores naturales y antropogénicos en un área la región pampeana declarada Paisaje Protegido, para contribuir a la toma de decisiones y gestión basada en el conocimiento. Se llevó a cabo una clasificación no supervisada de imágenes satelitales SPOT para seleccionar las áreas invadidas con vegetación arbustiva. Una serie de puntos en áreas invadidas fueron georreferenciadas en el campo para controlar la clasificación realizada por el sistema de información geográfica. Para medir la influencia de los factores analizados en los procesos de dispersión de las especies se utilizaron técnicas de regresión logística espacial. Los resultados mostraron que el $20,40 \%$ del área de estudio ha sido ocupada por especies exóticas de las cuales el 11,06\% eran plantaciones de árboles realizadas por el hombre y el 9,34\% corresponde a tres especies de arbustos exóticos que invaden diferentes sectores de paisaje. Genista monspesullana ha ocupado 307,85 ha, Rubus ulmifolius 237,82 ha y Spartium junceum 126,55 ha. Para explicar la propagación de $R$. ulmifolius, todas las variables analizadas, excepto las canteras y cavas, fueron significativas, pero las calles, caminos y senderos y las pircas tuvieron una mayor incidencia. Para $S$. junceum, las variables explicativas significativas fueron canteras y cavas, altitud y pendiente. Para G. monspesullana la variable explicativa fue calles, caminos y senderos.
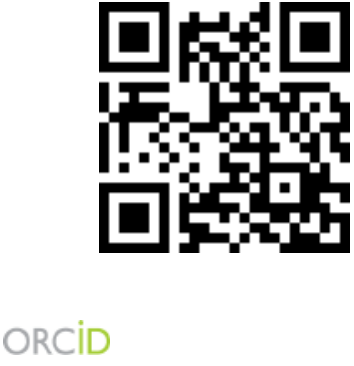

(D) 0000-0001-6013-6880 María Isabel Márquez

다 0000-0002-5008-8229 María Julia Kristensen

(1) 0000-0002-7716-8691 Juan Manuel Lavornia

(1) 0000-0003-4989-1230 Santiago Linares 
Palabras clave: Invasiones biológicas; Plantas exóticas invasoras; Sistema de Información Geográfica; Regresión logística espacial; Pastizal pampeano.

Resumo. Avaliação de fatores que afetam a distribuição espacial de arbustos exóticos para monitorar sua invasão em uma paisagem protegida do Pampa em Tandil, Argentina. Plantas exóticas, invasoras, que substituem espécies nativas representam uma ameaça global que compromete a conservação da biodiversidade simplificando e homogeneizando a paisagem. 0 presente estudo enfoca o problema das invasões que atinge uma área montanhosa dos Pampas (Tandil, Argentina) onde vários arbustos exóticos se comportam como invasores prejudicando a alta diversidade de pastagens nativas. 0 objetivo do estudo foi analisar, por meio de um sistema de informação geográfica, a distribuição das populações dos arbustos exóticas mais conspícuos, em relação a fatores naturais e antropogênicos, em uma área protegida da paisagem da Região do Pampa, a fim de contribuir para a tomada de decisões e gestão do conhecimento. As áreas de trabalho selecionadas foram aquelas com vegetação espontânea, realizando classificação não supervisionada de imagens de satélite SPOT. Vários pontos em áreas invadidas foram georreferenciados em campo para controlar a classificação feita pelo sistema de informação geográfica. Para medir a influência dos fatores analisados nos processos de dispersão das espécies, foram utilizadas técnicas de regressão logística espacial. Os resultados mostraram que $20,40 \%$ da área de estudo foi ocupada por espécies exóticas: das quais $11,06 \%$ foram plantações de árvores feitas pelo homem e 9,34\% correspondem a três espécies de arbustos que invadem diferentes setores da paisagem. Genista monspesullana ocupou 307,85 ha, Rubus ulmifolius 237,82 ha e Spartium junceum 126,55 ha. Para explicar a propagação de $R$. ulmifolius, todas as variáveis analisadas, com exceção das pedreiras, foram significativas, mas ruas, estradas e trilhas, e cercas de pedra tiveram maior incidência. Para $S$. junceum, as variáveis explicativas significantes foram pedreiras e cavas, altitude e declive. Para G. monspesullana, a variável explicativa foi ruas, estradas e trilhas.

Palavras-chave: Invasões biológicas; Plantas exóticas invasoras; Sistema de Informação Geográfica; Regressão logística espacial; Prados dos Pampas.

\section{Introduction}

Biodiversity plays a key role in the balance and stability of life in human development. It is responsible for several ecological services in ecosystems: taking part in the regulation of the composition of atmospheric gases, protecting coastal areas, regulating hydrological cycles and climate, generating and preserving soils, dispersing and degrading waste, pollinating crops and absorbing pollutants among others. From a diversity evaluation perspective there are four dimensions: productive, scientific, aesthetic and ethic (Ehrlich and Wilson, 1991). 
Biological diversity faces several threats worldwide. One is the invasion of alien species with a huge, insidious and generally irreversible impact. Invasive alien plants compromise biodiversity conservation taking the place of native species, simplifying and homogenizing the landscape. Thus, it is necessary before the species have spread widely that they be targeted for eradication if a feasible method can be identified (Mack et al., 2000; Simberloff et al., 2013; Simberloff, 2014). On a global scale, they can be as harmful for native species and ecosystems as habitat loss and degradation (IUCN, 2000).

The issue of invasive alien species was acknowledged and developed by Elton as early as 1958, giving rise to a great amount of books and essays which contributed to raise awareness on its global and local impact (e.g. Schuttler and Karez, 2008; Richardson, 2011; Lockwood et al., 2013).

Alien species can be defined as those outside their natural dispersal area which could not be there without direct or indirect human intervention and are capable of surviving and reproducing in the new environment (IUCN, 1999). Invasive species are the alien or exotic nonindigenous species that settle in a new natural or semi-natural habitat and thrive in detriment of native species (Mack et al., 2000).

Understanding the patterns and drivers of alien invasive species distribution is essential to provide management strategies for their control. Several hypotheses, such as disturbance, competition, climate, global change, introduction dynamics and null, have been proposed and tested by diverse authors. These hypotheses might explain the distribution patterns of alien plants (Rouget et al., 2015).

Conservation by means of protected areas is an effective way to protect native biodiversity (APN, 2007). A protected area is a geographical space which, through legal or other effective means, has been clearly defined, recognized, dedicated and managed to achieve long-term conservation of nature, its ecosystem services and associated cultural values (Dudley, 2008). Nevertheless, the invasion of alien plants constitutes a substantial threat undermining the capacity of protected areas to meet the objective of biodiversity conservation. The impact over species and communities described in numerous work and studies has not been sufficiently evaluated within the context of protected areas and is not always perceived by the public and decision makers. This includes ecosystem properties, biogeochemistry and ecosystem dynamics, ecosystem services and economics (Foxcroft et al., 2013a). Management is required to implement an invasive alien plant control programme as part of general management activities in protected areas. To this effect we lack the knowledge and support for effective scientifically based management solutions (Foxcroft et al., 2013b).

In the province of Buenos Aires, native vegetation - mainly herbaceous with some shrubs - has been intensely modified by the anthropization, agricultural and livestock development of the pampa ecoregion. It has been estimated that introduced species represent $23 \%$ of the flora, and the invasion of woody alien species has been recognized as a problem in different areas of the province (Ghersa et al., 2001; Vazquez and Aragón, 2002). The problem of alien plant invasion with 356 alien plant species recorded growing in natural or semi-natural areas of the Pampa, transcends the borders of Argentina as many species are shared with Brazil and Uruguay (Fonseca et al., 2013).

In the orographic system of Tandilia (Southeast of the Province of Buenos Aires) an area of 14,070 ha named "La Poligonal" was declared "Protected Landscape of Provincial Interest" (PLPI) by Provincial Law No. 14,126/2010 (Buenos Aires, 2010). This 
area, which includes the City of Tandil and the utilization of wild and productive land, does not escape the presence of invasive alien species. Woody species invasion, in addition to human activity, infringe upon the survival of native species - many of which are endemic because they are displaced or their habitat is drastically modified. The area is being invaded by several shrubs with different degrees of aggressiveness (OPDS, 2011). They turn into a problem because these mountains that emerge $524 \mathrm{~m}$ AMSL from the plains of the pampas, are a biodiversity hotspot and the habitat of several flora and fauna species, among endemic and exclusive of the region, which need conservation and deserve special attention. Some examples of local and regional endemic fauna are the Liolemus tandilensis Vega et al., 2008, Melanophryniscus sp. Gallardo, 1961, Sturnella defilippii (Bonaparte, 1851). Among flora, Poa iridifolia Hauman, Plantago tandilensis (Pilg.) Rahn, Nierembergia tandilensis (Kuntze) Cabrera, Lepidium tandilense Boelcke. Besides, some species have restricted distribution, such Mimosa tandilensis Speg., Bipinnula penicillata (Rchb. f.) Cisternas \& Salazar, Baccharis dracunculifolia DC. tandilensis Ssp. (Speg.) Giuliano, Parodia submammulosa (Lem.) R. Kiesling ssp. submammulosa, or restricted habitat areas in the province, such as saxicolous species that settle in rocky outcrops, like leather fern Rumohra adiantiformis (G. Forst.) Ching (Salle, 2010), several lichen species (Lavornia, 2009, 2015) and some cactaceae. Along with Ventania, it is also the nesting area of the Geranoaeatus melanoleucus (Vieillot, 1819), the only eagle that lives in the Province of Buenos Aires.

The urgent need to manage the PLPI becomes evident, but there is still very little basic information to allow proper management. The totality of alien species in the area is unknown and which of them behave as invasive has not been studied. Therefore, there is a need to diagnose both native and endemic as well as alien and invasive biodiversity in order to manage the area adequately and protect the native ecosystem. The purpose of this essay is to contribute to decision-making and environmental management based on knowledge of this protected area.

This study focuses on the problem of invasions occurring in a protected landscape area of a mountainous region of the Pampas (Tandil, Argentina) where several alien shrubs behave as invasive displacing a high diversity of native grassland. The general objective was to analyze, by means of geographical information system (GIS), the distribution of the most conspicuous alien bush populations in relation to certain natural and anthropogenic factors in a protected area of the pampa landscape.

The study is based on the hypothesis that there are some alien shrubs in the PLPI that behave as invasive, distributed differently in relation to their topographic, hydrographic and anthropogenic preferences. The specific objectives are as follows: (1) to establish the spatial distribution of the shrub species that result invasive and determine their relative importance in the area under study (2) to establish the natural and anthropogenic factors associated with their dissemination, and (3) to establish management recommendation based on the resulting information.

\section{Materials and methods}

\section{Study area}

The study area (Figure 1) of the current essay was named "Protected Landscape of Provincial Interest" by Provincial Law No. 14,126/2010 (Buenos Aires, 2010), ratified on April 15, 2010. Article 1 establishes that this area is in accordance with the "Poligonal" name given to the area by former Law No. 12,704/2010 (Buenos Aires, 2010), delimited by the intersection of National 
Route 226 and Provincial Route 74 and PR30. Article 2 states that the aim of the current Law is the conservation and preservation of the integrity of the geographical, geomorphic, touristic and urban landscape of this area. The PLPI protects different plant communities grouped into communities of the mountain soil in valleys and slopes, grassland and shrubs; water communities in water flows and saxicolous communities in rocky outcrops.

The study universe included all the invasive alien shrub populations present in the wilder areas within the Protected Landscape of Provincial Interest during the year 2015.

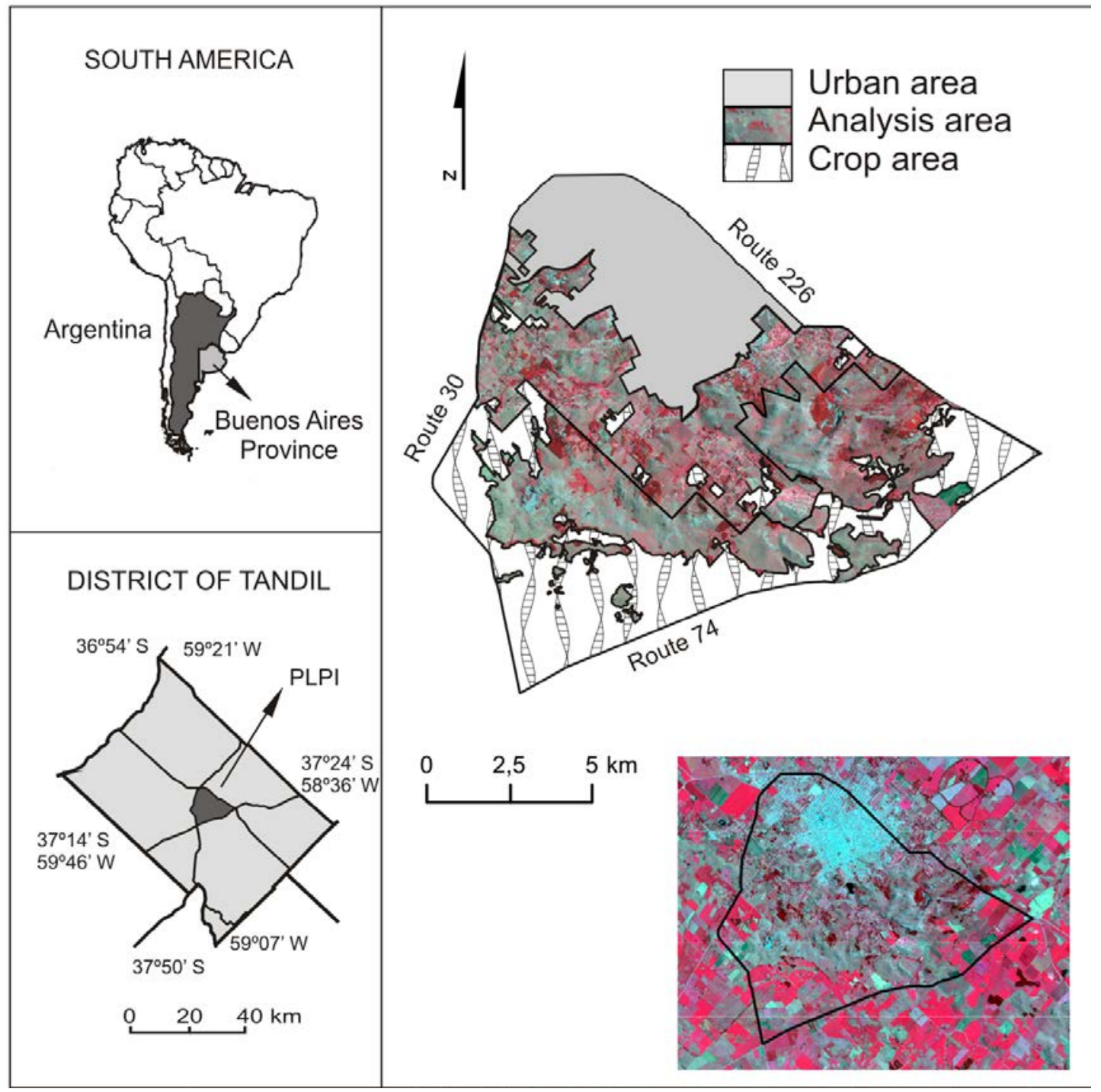

Figure 1. Study area. Protected Landscape of Provincial Interest (PLPI) in Tandil, Buenos Aires, Argentina. Satellite image and local zonification of PLPI: urban, analysis (complementary and rural areas), and crop areas (Municipalidad de Tandil, 2005). 
The study area is subject to diverse human activities such as tourism, climbing, rappel, trekking, mountain bike, construction, extensive cattle grazing, forestation and crops among others. Prior to Law 14,126/2010 (Buenos Aires, 2010), mining was carried out, several quarries remaining as evidence of their negative impact on the environment.

Both crop and urban zones were excluded from the study to work on the wilder patches. The studied area was called "analysis zone" (Figure 1) and it is composed of rural and complementary zones without crops.

\section{Treatment of geographic information using GIS \\ A geographical information} system was implemented as a database for invasions, which allowed the creation of all the thematic layers for each species recognized as alien invasive shrubs to determine if there is a relation between the invasion and any topographic, hydrographic or anthropogenic variables (Figure 2). The software used to accomplish this essay was ArcGis 10.1 (ESRI, 1995-2013).

The information sources to create each layer (Table 1) were the following:

- Topographic maps from the study area: sheets 3760-29 and 3760-23 from the Geographical Military Institute (IGM, 1955a,b).

- SPOT Satellite images provided by the National Commission of Spatial Activities (CONAE), from different dates (summer and winter of 2013, 2014 and 2015) and resolutions (Multispectral and panchromatic).

- "World Imagery" Basemap Image provided by ESRI (1995-2013), 30 cm resolution (ArcGIS $10.1 \circledR$ ).

- Geo-referenced points in field with GPS (Garmín eTrex Vista HCx ®) and field recognition.

Table 1. Sources used to generate thematic layers of GIS.

\begin{tabular}{|c|c|c|c|}
\hline Source & $\begin{array}{l}\text { Created thematic } \\
\text { layer }\end{array}$ & $\begin{array}{l}\text { Generated } \\
\text { thematic layer }\end{array}$ & Tool used \\
\hline \multirow[t]{2}{*}{ Topographic maps } & Contour lines & $\begin{array}{l}\text { Altitude (digital } \\
\text { land model) }\end{array}$ & $\begin{array}{l}\text { TIN to Raster ( } 3 D \text { Analyst } \\
\text { tools. Conversion from } \\
\text { TIN) }\end{array}$ \\
\hline & & Slope & $\begin{array}{lr}\text { Surface Slope (3D Analyst } \\
\text { Tools. } & \text { Triangulated } \\
\text { surface) } & \end{array}$ \\
\hline $\begin{array}{l}\text { Topographic maps, } \\
\text { field trips and } \\
\text { Basemap image. }\end{array}$ & $\begin{array}{l}\text { Permanent, temporary } \\
\text { and conduits streams } \\
\text { Artificial water bodies } \\
\text { Quarries and pits } \\
\text { Stone fences }\end{array}$ & & \\
\hline $\begin{array}{l}\text { Satellite images, field } \\
\text { trips and Basemap } \\
\text { image }\end{array}$ & $\begin{array}{l}\text { Streets, roads and } \\
\text { trails }\end{array}$ & $\begin{array}{l}\text { Rock outcrops } \\
\text { Invasion maps }\end{array}$ & $\begin{array}{lr}\text { Iso Cluster } & \text { Unsupervised } \\
\text { Classification } & \text { (Spatial } \\
\text { analyst } & \text { tools. } \\
\text { Multivariate) } & \\
\end{array}$ \\
\hline
\end{tabular}




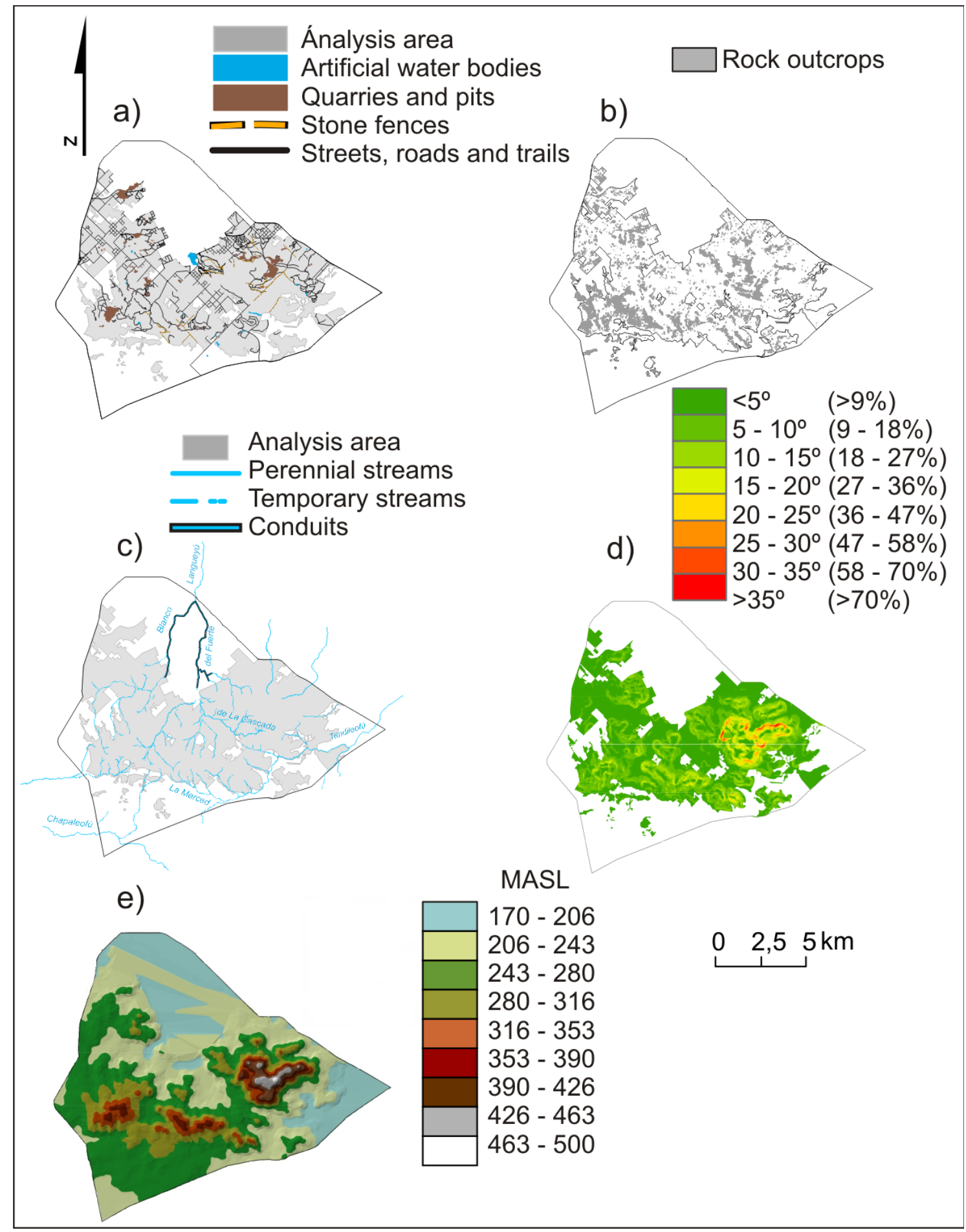

Figure 2. Topographic, hydrographic and anthropogenic variables in the analysis area. a) Artificial water bodies, quarries and pits, stone fences, streets, roads and trails; b) surfaces covered by rock outcrops (\%); c) permanent, temporary and conduit streams; d) slope classes in grades $\left({ }^{\circ}\right)$ and percentage (\%); e) digital elevation model showing altitude classes (m a.s.l.) 


\section{Identification of invasive alien species distribution}

Previous studies have indicated that the problem species that have become invasive in the area are three shrubs: Spartium junceum L., Genista monspessulana (L.) L.A.S. Johnson, and Rubus ulmifolius Schott (Pose and Kristensen, 2010; OPDS, 2011) and thus we focus attention on them.

Winter and summer satellite images of 2013, 2014, and 2015 of the PLPI were analysed in order to identify the shrub species that behave as invasive in the protected area. Besides, during the multiple field trips carried out, species were collected for herborization and identification with stereo microscope. Numerous GPS points with invaded areas were marked in those trips.

After analysing several satellite images, it was decided to work on a multispectral SPOT image of February 24 2015 (Figure 1), in order to get an updated invasion occurrence, because most of the samples were close to that date. The resolution of the image selected is $10 \times 10 \mathrm{~m}$. The representation system used was POSGAR 1994 Argentina zone 5 .

The study area was divided into urban, rural and complementary zones according to the Municipal Territory Development Plan (Municipalidad de Tandil, 2005).

Crop areas were excluded from the essay because the presence of invasive species is disregarded while there are agricultural activities. These are considered less important for biodiversity conservation, due to their strong anthropization.

\section{classification}

\section{Iso cluster unsupervised}

Classification was conducted in order to recognise the areas invaded and to establish the spatial distribution of invasive alien shrubs. Every classification reached was checked in field trips. The species with greater distribution in the area were recognised and a fact sheet with taxonomic characteristics and phenological development was made for each one.

A layer was generated for each alien invasive shrub with its spatial distribution, and the absolute (ha) and relative (\%) area occupied by each species was calculated.

\section{Association between the invasive species and natural and anthropogenic factors}

A layer with vectorial information was generated for each of the natural and anthropogenic factors analysed.

In order to map the natural factors, the level curves were digitalized, using vectorial edition tools and topographic maps of the area. A Digital Elevation Model was drawn up, which allowed the classification of the area by altitude (m AMSL) and slope.

Water flows were digitalized differentiated in permanent, temporary, and conduits.

In order to map anthropogenic factors, streets, roads and trails were digitalized in a layer, and archaeological or historical stone fences in another. Quarries and pits were drawn up, as well as artificial water bodies.

When assessing the association between invasive species and factors, our priority, was to incorporate the entire universe within the analysis area, represented in our digital model by all the pixels within the analysis area that have values of factors that allow evaluating the magnitude of its incidence on the invasive species studied.

To this end we generated maps of continuous distribution of values, both for distance (in the case of roads, streams, rock outcrops, quarries, stone fences), as well as for altitude and slope (Figure 3). 


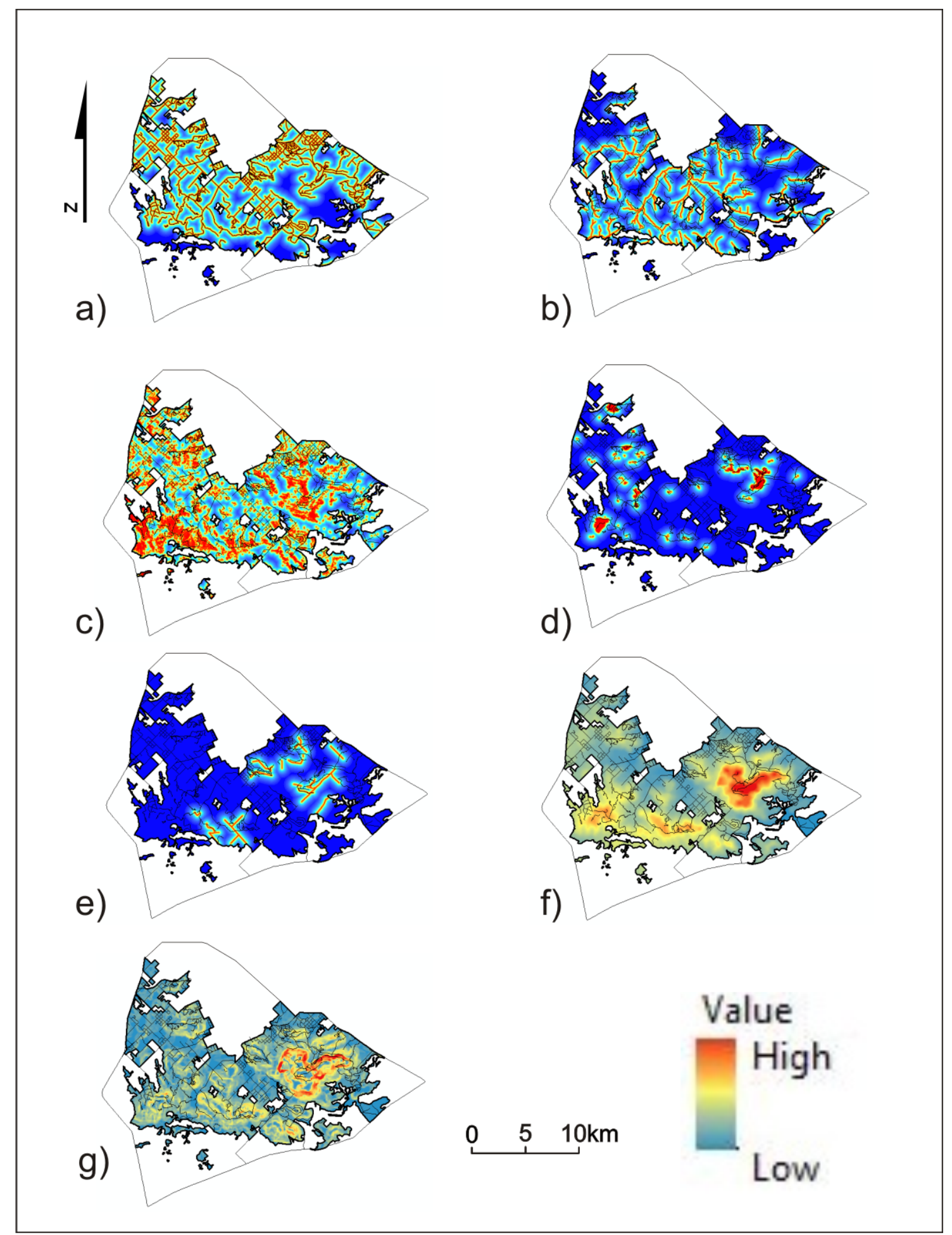

Figure 3. Continuous factor distribution maps. a) distance to streets, roads and trails; b) distance to permanent, temporary and conduit streams; c) distance to rock outcrops; d) distance to quarries and pits; e) distance to stone fences; f) slope classes; g) altitude classes. 
The values obtained from the continuous maps, stored in database, permitted a logistic regression analysis using statistical InfoStat software (Di Rienzo et al., 2013).

This analysis technique allows modeling the relationship between a response variable of dichotomous nature in relation to one or more independent or regressor variables. The coefficients of the linear combination that models this relationship allow estimating the ratio of cross products (odd ratio) for each regressor variable. The size of the elaborated data matrix was 717,550 rows by 7 columns ( 7 variables used).

The logistic regression model can be used to predict the probability $\left(\mathrm{p}_{\mathrm{i}}\right)$ that the response variable assumes a given value, for example the probability of success $(y=1)$ in a dichotomous variable that assumes the values 0 and 1 .

For a binary response, the simple logistic regression model (with a regressor) has the following formula:

\section{$\operatorname{Logit}\left(p_{i}\right)=\log \left(p_{i} /\left(1-p_{i}\right)\right)=\alpha+\beta X_{i}$}

Where $p_{i}$ is the probability of success given $X_{i}, \alpha$ is the ordinate at (constant) origin, $\beta$ is the slope or regression coefficient associated with $X$, and $X$ is the explanatory variable. Then, in logistic regression, the Logit transformation of the probability of success is modeled as a linear function of one or more explanatory variables.

The parameters to be interpreted in this analysis are:

Est.: The coefficient of regression provides information on the strength and direction in which each regressor variable will affect the probability of occurrence of success in the dependent.

O.R.: The ratio of cross products (odd ratio) for each regressor variable provides information on the proportion and amount of variation of the probability of presence/absence of the dependent variable according to changes in the units of the regressor variable.

$p$ : The result of the hypothesis test $\mathrm{H} 0: \mathrm{Bi}=0$ versus $\mathrm{Bi} \neq 0$ for $\mathrm{a}$ significance level $\mathrm{a}=0.0001$, allows to evaluate the significance of the relationship between regressor and dependent variables.

-2 (L0-L1): Contains -2 times the difference of the logarithms of the likelihood between the reduced model (LO) and the complete model (L1). It is smaller the more explanatory the variable and this happens when the distribution of the variables resembles a logistic curve, thus allowing to select the order to elaborate a predictive model.

The factors are analyzed individually to find out which make a significant contribution to the explanation/prediction of the dispersion of each species.

\section{Results}

Out of the 14,070 ha of PLPI, 2,723 correspond to urban areas, 3,920 to complementary areas, and 7,427 to rural areas. As a result, the analysis area, the more natural patches without urban or crop areas (Figure 1) was 7190 ha.

The image classification of the 7,190 ha corresponding to the area of analysis differentiated 176 classes; many of them corresponded to alien invasive species. Image analysis and field trips allowed identifying the three mentioned species in the area that behave as invasive and occupy large surfaces. Their population structure, with different age classes and the evidence that they were not planted, allowed to diagnose their invasive behavior (Figure 4). 


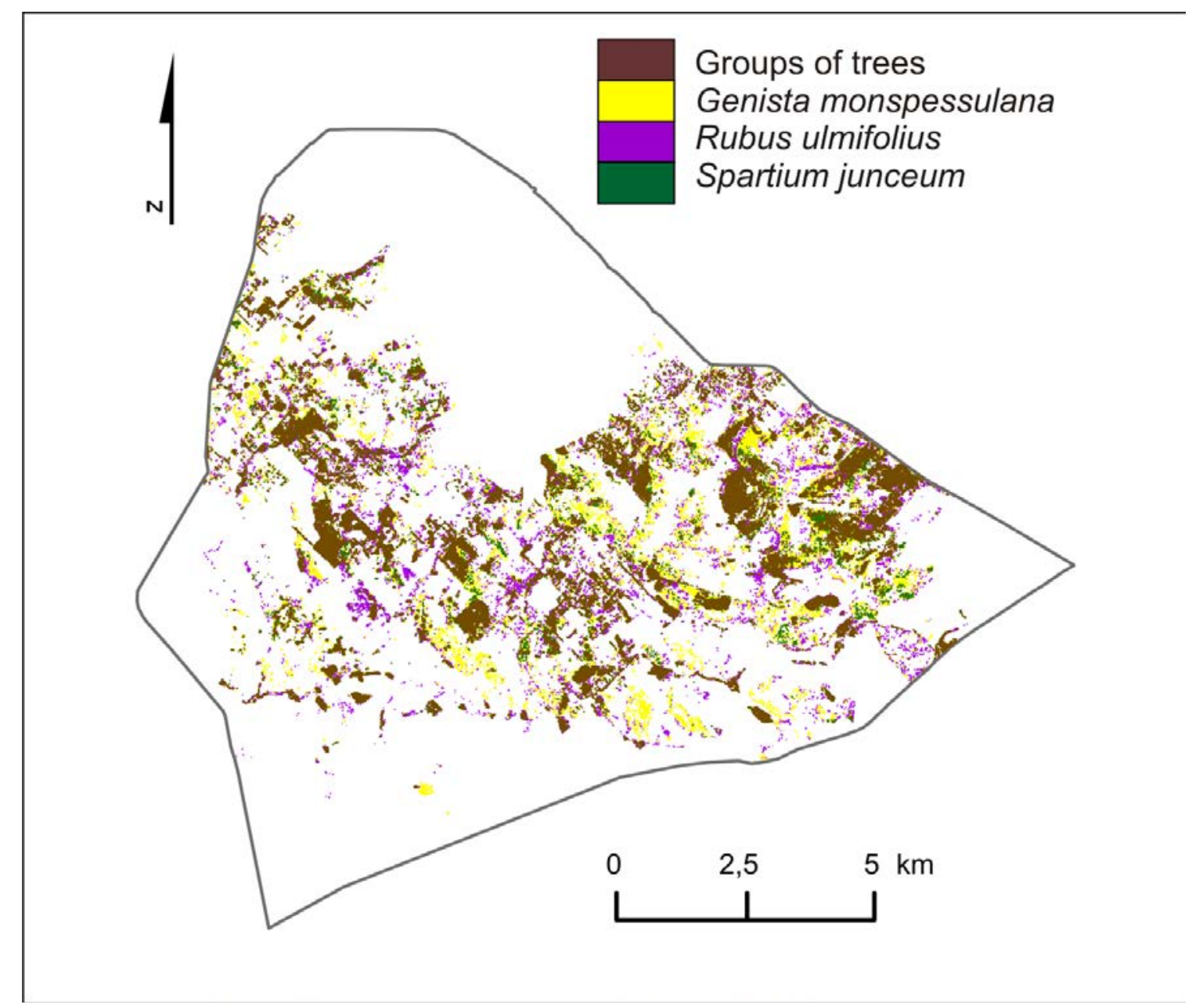

Figure 4. Distribution of the three alien species in the analysis area (G. monspessulana, R. ulimifolus, $S$. junceum) and groups of trees, from the analysis of the satellite image classification.

Out of the total 3,481 ha of the complementary analysis area, 717.87 ha are occupied by alien woody plants, which represent $20.62 \%$ of the complementary area. These are constituted by $10.95 \%$ (381.45 ha) of groups of alien trees, planted or invaders, $4.09 \%$ (142.48 ha) of G. monspessulana, $3.64 \%$ (126.87 ha) of $R$. ulmifolius, and $1.93 \%$ (67.07 ha) of S. junceum (Table 2).
Out of the total 3,709 ha of the rural analysis area, 748.81 ha are occupied by alien woody plants, which represents $20.19 \%$ from the rural. These consist in $11.13 \%$ (413.01 ha) of groups of alien trees, planted or invaders, $4.46 \%$ (165.37 ha) of G. monspessulana, 2.99\% (110.95 ha) of R. ulmifolius, and $1.60 \%$ (59.48 ha) of S. junceum (Table 2). 
Table 2. Absolute (ha) and relative (\%) coverage of the woody alien invasive species within the analysis area.

\begin{tabular}{lcccccc}
\hline \multirow{2}{*}{ Species } & \multicolumn{3}{c}{$\begin{array}{c}\text { Surface occupied in different areas } \\
\text { Aomplementary }\end{array}$} & \multicolumn{2}{c}{ Rural } & \multicolumn{2}{c}{$\begin{array}{c}\text { Analysis area } \\
\text { ha }\end{array}$} & \% & ha & \% & ha & \% \\
\hline Genista monspessulana & 142.48 & 4.09 & 165.37 & 4.46 & 307.85 & 4.28 \\
Rubus ulmifolius & 126.87 & 3.64 & 110.95 & 2.99 & 237.82 & 3.30 \\
Spartium junceum & 67.07 & 1.93 & 59.48 & 1.60 & 126.55 & 1.76 \\
Groups of trees & 381.45 & 10.95 & 413.01 & 11.13 & 794.46 & 11.05 \\
\hline Total alien & 717.87 & 20.62 & 748.81 & 20.19 & 1466.68 & 20.40 \\
\hline Total analysis area & 3481 & 20.62 & 3709 & 20.19 & 7190 & 100 \\
\hline
\end{tabular}

Adding the invasion figures in complementary and rural areas, the result is that $20.40 \%$ of the analysis area is under an invasive process (Table 2). The remaining $79.60 \%$ is occupied by crops, rock outcrops, saxicolous communities, native shrubs and grasslands, and non-classified areas (pits, streets, bare soil, among others).

The greater areas occupied by alien woody species correspond to alien groups of trees, which are mostly planted to be used as curtains for noise and dust from quarries. Even though they were not analysed in this essay, it would be important to differentiate which of those reproduce spontaneously and behave as invasive; there is evidence that some of these alien arboreal plants produce second-growths (Aldanondo et al., 2004).

From the three shrub species that behave as invasive in the Protected Landscape, G. monspesullana occupied the largest area, secondly $R$. ulmifolius and thirdly $S$. junceum. It was expected that complementary areas would be more invaded than rural, but both complementary and rural zones are invaded by $20 \%$.

\section{Relation between problem species and natural and antropoghenic factors}

The analysis of individually evaluating each factor to determine the influence on the emergence of each invasive species yielded the following results.

In the case of $R$. ulmifolius (Table 3 ), it is possible to conclude that except quarries and pits all variables are significant $(\mathrm{p}<0.0001)$. According to their explanatory potential three groups would appear within them (-2 (L0-L1): streets, roads and trails and stone fences with strong incidence on the explanation of the propagation of the $R$. ulmifolius, slopes with moderate incidence and, water flows, altitude and rock outcrops with low incidence.

For the $S$. junceum the results were quite different (Table 4), two variables did not pass the test of significance $p$ (water flows and stone fences), while on this occasion the most explanatory were quarries and pits, and altitude and slope; streets, roads and trails with moderate inclusion, and rock outcrops with low incidence. 
Table 3. Logistic regression analysis between maps of distribution of $R$. ulmifolius and distance to natural and anthropogenic factors. The parameters interpreted were the coefficient of regression (Est.), the ratio of cross products for each regressor variable (O.R.), the -2 times the difference of the logarithms of the likelihood between the reduced model (L0) and the complete model (L1), and the result of the hypothesis test for a 0.0001 significance level $(p)$.

\begin{tabular}{clllrr}
\hline Order & \multicolumn{1}{c}{ Variables (distance) } & Est. & O.R. & -2(L0-L1) & \multicolumn{1}{c}{$\boldsymbol{p}$} \\
\hline 1 & Quarries and pits & 0.001 & 1 & 2.56 & 0.1084 \\
2 & Streets, roads and trails & -0.02 & 0.98 & 44.44 & $<0.0001$ \\
3 & Stone fences & -0.003 & 1 & 74.84 & $<0.0001$ \\
4 & Slope & -0.03 & 0.97 & 438.03 & $<0.0001$ \\
5 & Water flows & -0.08 & 0.92 & 1067.97 & $<0.0001$ \\
6 & Altitude & -0.01 & 0.99 & 1871.18 & $<0.0001$ \\
7 & Rocks outcrops & 0.33 & 1.39 & 2165.25 & $<0.0001$ \\
\hline
\end{tabular}

Table 4. Logistic regression analysis between maps of distribution of $S$. junceum and distance to natural and anthropogenic factors. The parameters interpreted were the coefficient of regression (Est.), the ratio of cross products for each regressor variable (O.R.), the -2 times the difference of the logarithms of the likelihood between the reduced model (L0) and the complete model (L1), and the result of the hypothesis test for a 0.0001 significance level $(p)$.

\begin{tabular}{clrrrr}
\hline Order & Variables & \multicolumn{1}{l}{ Est. } & O.R. & -2(L0-L1) & $\boldsymbol{p}$ \\
\hline 1 & Water flows & 0.002 & 1 & 0.49 & 0.4825 \\
2 & Stone fences & 0.001 & 1 & 9.52 & 0.0020 \\
3 & Quarries and pits & -0.01 & 0.98 & 84.74 & $<0.0001$ \\
4 & Altitude & -0.001 & 1 & 91.34 & $<0.0001$ \\
5 & Slope & 0.02 & 1.02 & 97.66 & $<0.0001$ \\
6 & Streets, roads and trails & -0.10 & 0.90 & 528.88 & $<0.0001$ \\
7 & Rock outcrops & 0.40 & 1.50 & 1902.69 & $<0.0001$ \\
\hline
\end{tabular}

Finally, the G. monspesullana (Table 5) shows three variables that did not exceed the levels of significance adopted, altitude, quarries and pits and water flows, the most explanatory and determinant variable is streets, roads and trails, the rest present very high values of -2 (L0-L1), evidencing very low incidence on the probability of existence/non-existence of this species.

Table 5 Logistic regression analysis between maps of distribution of $G$. monspesullana and distance to natural and anthropogenic factors. The parameters interpreted were the coefficient of regression (Est.), the ratio of cross products for each regressor variable (O.R.), the -2 times the difference of the logarithms of the likelihood between the reduced model (L0) and the complete model (L1), and the result of the hypothesis test for a 0.0001 significance level (p).

\begin{tabular}{clllrc}
\hline Order & Variables & Est. & O.R. & - 2(L0-L1) & $\boldsymbol{p}$ \\
\hline 1 & Altitude & -0.000 & 1 & 0.12 & 0.7334 \\
2 & Quarries and pits & -0.001 & 1 & 4.5 & 0.0339 \\
3 & Water flows & -0.01 & 0.99 & 9.24 & 0.0024 \\
4 & Streets, roads and trails & 0.02 & 1.02 & 51.40 & $<0.0001$ \\
5 & Stone fences & -0.01 & 0.99 & 1212.19 & $<0.0001$ \\
6 & Slope & 0.04 & 1.04 & 1449.42 & $<0.0001$ \\
7 & Rock outcrops & 0.44 & 1.54 & 5338.89 & $<0.0001$ \\
\hline
\end{tabular}

Rev. Bras. Gest. Amb. Sustent., 2019, vol. 6, n. 13, p. 427-444. 


\section{Discussion}

Determiners of plant invasion include ecological and historical factors that result in particular land use types and spatial patterns. The bioma of the pampa grasslands has alien plant invader species that are shared between Argentina, Uruguay and Brazil, presenting transnational similarities regarding ecological features, a common colonization history, and development trends (Fonseca et al., 2013). The whole region has suffered alterations associated with cattle ranching, nutrient addition, changes in fire regimes and enrichment with non-native forage species. The Pampa remnants may be especially vulnerable to invasive alien species (Hobbs and Huenneke, 1992; Chaneton et al., 2002). Most of these invasive plants are native of Europe, Asia and Africa, and many of them have been associated with some human use, e.g. gardening (Fonseca et al., 2013), like the three species analyzed by the study area.

In the case of $R$. ulmifolius (Table 3 ), we had thought that it was associated with streams, because in the field most streams are covered with this species, but the study proved that it is not exclusive, it is also present in areas far from streams, demonstrating its great invasiveness potential.

For the S. junceum (Table 4), the close relationship between the presence of this broom and the quarries can be explained by the cultural roots of immigrant stone cutters who settled in the area and planted this shrub brought from their European countries of origin.

Finally, in the case of $G$. monspesullana (Table 5), streets and roads are the most explanatory variable perhaps because men and animals contribute to disperse its seeds as they tread on them, and principally because this species takes advantage of the altered places with soil removed and devoid of vegetation in order to germinate. Pose and Kristensen (2010) found that the increment of slope is positively related with the species coverage, while rockiness and altitude had a negative impact. The stronger relation of invasiveness occurred with anthropic modifications, especially where mining, streets and roads converged.

Over the rock outcrops, occupied by native plant communities of chasmophitic species, none of these three alien species were present, probably due to the limitations that constitute the absence of a deep and developed soil, added to extreme microclimatic conditions of rocky habitat (Kristensen and Frangi, 1996), conditions to which only the saxicolous vegetation can be adapted.

The assemblies of invasive species would be controlled by the hard environmental barriers, which constrain the distribution of biomes (Rouget et al., 2015), however, at landscape level, where different communities of the same biome interact with human activities, results showed here that it is possible for other hypotheses to work better. In this study, results allow to consider that "the weed-shaped hole" hypothesis with main driver of patterns is disturbance (abiotic), especially the addition of disturbance factors, which could explain the local distribution of the three analyzed species.

This research provides insight to understanding of invasion dynamics in PLPI. Mapped distribution of principal problem species offers data about potential drivers of invasions, which is crucial for successful long-term management. Better and more focused action is urgently needed: improved capacity to prevent invasions, prompt reaction to new incursions, and increased effort to manage wellestablished invasive species (Foxcroft et al., 2013a,b). We agree with these authors that efforts to lessen the sciencemanagement divide are especially important in protected areas. 
Overcoming this barrier will require partnership between local, municipal, regional and national organizations, including the social aspects of human perception in the analysis.

We are aware of the need to provide information about the range, scope, and consequences of the less obvious effects of invasions, such as those affecting ecosystem processes, and thus contribute to elucidate the complexities of invasions and the need to explore realistic management options to managers and the public (Simberloff et al., 2013). We encourage that to happen in the PLPI.

\section{Conclusions}

The study area is occupied by alien woody species in $20.40 \%$, of which $11.06 \%$ are arboreal species not studied in the present investigation. Most correspond to planted trees.

The remaining 9.34\% correspond to the three alien shrub species studied.

These three could be recognized as invasive by their dense populations dominating large areas which are not shared with other species, and by the characteristics of their propagation. Of these, the largest surface was occupied by the $G$. monspesullana (307.85 ha), then the $R$. ulmifolius (237.82 ha) and finally the $S$. junceum (126.55 ha).

The degree of invasion occurs in similar percentages both in the complementary area and the rural area. This study showed the differential incidence of dispersion factors for each of the analysed species, each of them associated with different natural and anthropogenic variables. The three were distributed differentially within the analysis area, occupying different sectors of the landscape.

According to the analysis, the communities most affected by the invasion would be those of mountain soil in valleys and slopes, grasslands and shrubs, and water communities, not those of rock outcrops. Therefore, more conservation efforts are needed in the two first.

\section{Conflicts of interest}

Authors declare that they have no conflict of interests.

\section{References}

Aldanondo, C. G.; Kristensen, M. J; Pose, M. P. Las leñosas exóticas en las Sierras de Tandil. Proceding of II Reunión Binacional de Ecología, XXI Reunión Argentina de Ecología y XI Reunión de la Sociedad de Ecología de Chile, Mendoza, 2004.

APN - Administración de Parques Nacionales. Lineamientos estratégicos para el manejo de especies exóticas en la Administración de Parques Nacionales. Administración de Parques Nacionales. Buenos Aires, 2007. Available from: <https://sib.gob.ar/ archivos/version_final_Lineamientos.pdf $>$.

Accessed on: Jun. 2, 2019.

Buenos Aires. Ley no $\mathbf{1 2 . 7 0 4 / 2 0 1 0 .}$ Establecen y regulan las condiciones para las áreas que sean declaradas "Paisaje Protegido de Interés Provincial" o "Espacio Verde de Interés Provincial", con la finalidad de protegerlas y conservarlas. Available from: <http://www.gob.gba.gov.ar/legislacion/legi slacion/l-12704.html>. Accessed on: Jun. 2, 2019.

Buenos Aires. Ley no 14.126, of March 23, 2010. Paisaje Protegido de Interés Provincial del Partido de Tandil. Available from: <http://www.gob.gba.gov.ar/legislacion/legi slacion/l-14126.html>. Accessed on: Jun. 2, 2019.

Chaneton, E. J.; Perelman, S. B.; Omacini, M.; León, R. J.C. Grazing, environmental heterogeneity, and alien plant invasions in temperate pampa grasslands. Biological Invasions, v. 4, no. 1/2, p. 7-24, 2002. https://doi.org/10.1023/A:1020536728448

Di Rienzo, J. A.; Casanoves, F.; Balzarini, M. G.; González, L.; Tablada, M.; Robledo, C. W. InfoStat versión 2013. Grupo InfoStat, FCA, Universidad Nacional de Córdoba, Argentina. 2013. Available from: <http://www.infostat.com.ar>. Accessed on: Jun. 2, 2019. 
Dudley, N. (Ed.). Guidelines for applying protected area management categories. Switzerland: Gland, IUCN, 2008.

Ehrlich, P. R.; Wilson, E. O. Biodiversity studies: Science and policy. Science, v. 253, p. 758-762, 1991. https://doi.org/10.1126/ science.253.5021.758

Elton, C. S. The ecology of invasions by animals and plants. London: Methuen, 1958.

ESRI - Environmental Systems Research Institute. ArcGIS. Tutorials and reference manuals. Redlands: ESRI, 1995-2013.

Fonseca, C.; Guadagnin, D.; Emer, C.; Masciadri, S.; Germain, P.; Zalba, S. Invasive alien plants in the pampas grasslands: A tri-national cooperation challenge. Biological Invasions, v. 15 , no. 8, 17511763, 2013. https://doi.org/10.1007/ s10530-013-0406-2

Foxcroft, L. C.; Pyšek, P.; Richardson, D. M.; Pergl, J.; Hulme P. E. The bottom line: Impacts of alien plant invasions in protected areas. In: Foxcroft, L. C.; Pyšek, P.; Richardson, D. M.; Genovesi, P. (Eds.). Plant invasions in protected areas: Patterns, problems and challenges. Dordrecht: Springer, 2013a. p. 19-41.

Foxcroft, L. C.; Richardson, D. M.; Pyšek, P.; Genovesi, P. Invasive alien plants in protected areas: Threats, opportunities, and the way forward. In: Foxcroft, L. C.; Pyšek, P.; Richardson, D. M.; Genovesi, P. (Eds.). Plant invasions in protected areas: Patterns, problems and challenges. Dordrecht: Springer, 2013b. p. 621-640.

Ghersa, C. M.; De la Fuente, E.; Suárez, S.; León, R. J. C. Woody species invasions in the rolling Pampa grasslands, Argentina. Agriculture, Ecosystems and Environment, v. $88, \quad$ no. $3, \quad$ p. $271-278,2001$. https://doi.org/10.1016/S0167-8809(01) 00209-2

Hobbs, R. J.; Huenneke, L. F. Disturbance, diversity, and invasion: Implications for conservation. Conservation Biology, v. 6, no. 3, p. 324-337, 1992.

IGM Instituto Geográfico Militar. Hoja 376023 "Tandil". Carta topográfica, E: 1:100.000, Equidistancia $5 \mathrm{~m}$. Buenos Aires: Instituto Geográfico Militar, 1955a.
IGM - Instituto Geográfico Militar. Hoja 376029 "Sierras de Tandil". Carta topográfica, E: 1:50.000, Equidistancia 10 m. Buenos Aires: Instituto Geográfico Militar, 1955b.

IUCN - Unión Internacional para la Conservación de la Naturaleza. Especies invasoras exóticas. Cuarta Reunión del Órgano Subsidiario de Asesoramiento Científico, Técnico y Tecnológico, Montreal, Canadá, Unión Internacional para la Conservación de la Naturaleza, 1999.

IUCN - Unión Internacional para la Conservación de la Naturaleza. IUCN guidelines for the prevention of biodiversity loss caused by alien invasive species. Approved by the 51st meeting of the IUCN Council, Gland Switzerland, 2000. Available from: <https://portals.iucn.org/library/ efiles/documents/Rep-2000-052.pdf>.

Accessed on: Jun. 2, 2019.

Kristensen, M. J.; Frangi, J. L. Mesoclimas de roquedales de la Sierra de la Ventana. Ecología Austral, v. 6, no. 2, p. 115-122, 1996.

Lockwood, J. L.; Hoopes, M. F.; Marchetti, M. P. Invasion Ecology. 2. ed. London, UK: Wiley-Blackwell, 2013.

Mack, R. N.; Simberloff, D.; Lonsdale, W. M.; Evans, H.; Clout, M.; Bazzaz, F. A. Biotic invasions: causes, epidemiology, global consequences, and control. Ecological Applications, v. 10, p. 689-710, 2000.

Municipalidad de Tandil. Buenos Aires, Argentina. Ordenanza no 9,865, of November 15, 2005. Plan de Desarrollo Territorial de Tandil. Available from: $<$ https://www.mininterior.gov.ar/planificaci on/pdf/planes-loc/BUENOSAIRES/PlanDesarrollo-Territorial-Tandil.pdf $>$. Accessed on: Jun. 2, 2019.

OPDS - Organismo Provincial para el Desarrollo Sostenible, Provincia de Buenos Aires, Argentina. Resolución no 17, of February 5, 2011. Plan de Manejo Ambiental "La Poligonal". Available from: <http://www.gob.gba.gov.ar/legislacion/legi slacion/opds-11-17.html>. Accessed on: Jun. $2,2019$.

Pose, M. P.; Kristensen, M. J. La retamilla, una invasora en las sierras de Tandil. In: CINEA Centro de Investigaciones y Estudios Ambientales. (Ed.). Estudios ambientales II. Buenos Aires: Centro de Investigaciones y 
Estudios Ambientales, Centro de la Provincia de Buenos Aires National University, REUN, 2010. p. 183-192.

Richardson, D. M. Fifty years of invasion ecology. The legacy of Charles Elton. New York: Wiley-Blackwell, 2011.

Rouget, M.; Hui, C.; Renteria, J.; Richardson, D. M.; Wilson, J. R. U. Plant invasions as a biogeographical assay: Vegetation biomes constrain the distribution of invasive alien species assemblages. South African Journal of Botany, v. 101, p. 24-31, 2015. https://doi.org/10.1016/j.sajb.2015.04.009

Salle, A. J. Un recurso de vida silvestre de las sierras bonaerenses: el "helecho piedra" (Rumohra adiantiformis (G. Forst.) Ching). Buenos Aires: Ciencias Humanas Faculty, Centro de la Provincia de Buenos Aires National University, 2010. (Grade thesis).

Schüttler, E.; Karez, C. S. (Eds.) Especies exóticas invasoras en las Reservas de Biosfera de América Latina y el Caribe. Un informe técnico para fomentar el intercambio de experiencias entre las Reservas de Biosfera y promover el manejo efectivo de las invasiones biológicas. Montevideo: UNESCO, 2008.
Simberloff, D. Biological invasions: What's worth fighting and what can be won? Ecological Engineering, v. 65, p. 112-121, 2014. https://doi.org/10.1016/j.ecoleng. 2013.08.004

Simberloff, D.; Martin, J. L.; Genovesi, P.; Maris, V.; Wardle, D.; Aronson, J.; Courchamp, F.; Galil, B.; García-Berthou, E.; Pascal, M.; Pyšek, P.; Sousa, R.; Tabacchi, E.; Vilà, M. Impacts of biological invasions: What's what and the way forward. Trends in Ecology \& Evolution, v. 28, no. 1, p. 58-66, 2013. https://doi.org/10.1016/j.tree.2012.07.013

Vázquez, D.; Aragón, R. Introduction. Biological Invasions, v. 4, p. 1-5, 2002. https://doi.org/10.1023/A:1020516626844

License information: This is an open-access article distributed under the terms of the Creative Commons Attribution License, which permits unrestricted use, distribution, and reproduction in any medium, provided the original work is properly cited. 